\title{
Childhood Extracranial Germ Cell Tumor
}

National Cancer Institute

\section{Source}

National Cancer Institute. Childhood Extracranial Germ Cell Tumor. NCI Thesaurus. Code C68627.

A childhood benign or malignant germ cell tumor arising from an anatomic site other than the brain. 